\title{
Kajian Kriminologi dan Hukum Pidana terhadap Perilaku Vigilantisme pada Masyarakat
}

\author{
Beridiansyah $^{1}$
}

\begin{abstract}
Abstrak. Pembangunan yang sedang berlangsung diIndonesia saat ini membawa berbagai dampak baik pengaruh positif maupun negatif, pengaruh tersebut juga berdampak kepada kebiasaan (habit) pada masyarakat dalam menyikapi setiap permasalahan sosialyang terjadi agar dapat diselesaikan dengan cepat dan seketika itu juga, sehingga pemaksaan kehendak yang tidak jarang disertai dengantindakan kekerasan berupa tindakan main hakim sendiri dan melakukan tindakan yang melanggar hukum lainnya dengan mengabaikan asas praduga tidak bersalah (presumption of innocence) yang kita anut dalam sistem penegakan hukum di negara kita. Tujuan dari penulisan jurnal ini untuk mencari penyebab terjadinya tindakan main hakim sendiri (vigilantisme) pada masyarakat. Untuk mengetahui tentang vigilantisme ini maka yang menjadi pembahasan adalah apa yang dimaksud dengan vigilantisme dan kejahatan dan bagaimana pendekatan kriminologi dan hukum pidana terhadap vigilantisme. Tindakan vigilantisme merupakan bentuk kekecewaan masyarakat terhadap kekurangtanggapan aparat penegak hukum dalam menyikapi permasalahan yang dihadapi masyarakat.
\end{abstract}

Kata Kunci: Hukum, Kriminologi, Vigilantisme.

Abstract. The ongoing construction companies currently carry a wide range of impacts both positive or negative influence, these effects also impacted the habits on society in addressing any social problems that happen to be settled quickly and instantly, so the imposition of the will is not uncommon accompanied by acts of violence in the form of vigilantism and perform other unlawful acts by ignoring the presumption of innocence that we have adopted in the law enforcement system in our country. The purpose of writing this journal to find the cause of vigilantism on society. To know more about this then vigilantism in question is what is meant by vigilantism and crime and how the approach of criminology and criminal law against vigilantism. Act of vigilantism is a form of public disappointment against careless law enforcement agencies in addressing the problems faced by the community.

Keywords: Law, Criminology, Vigilantism.

\section{PENDAHULUAN}

Tindak kekerasan yang terjadi saat ini berada pada kondisi yang mengkhawatirkan, hal tersebut dapat kita cermati dari perilaku masyarakat dalam menyikapi setiap permasalahan sosial yang terjadi, pemaksaan kehendak dan menjustice seseorang/kelompok bersalah tanpa melalui proses hukum. Tindakan main hakim sendiri akan menimbulkantirani-tirani baru pada bentuk negara yang legalapabila tidak dilakukan langkahlangkah preemtif sejak dini akan menimbulkan anomie ditengah-tengah masyarakat, tindakan main hakim sendiri adalah kejahatan dan sangat bertentangan dengan nilai-nilai luhur yang dianut oleh bangsa Indonesia yang sangat menjunjung tinggi rasa tolong menolong dan musyawarah untuk mufakat dalam mencari solusi (problem solving) dalam mengatasi setiap permasalahan yang terjadi, sehingga tindakan main hakim sendiri ini harus dihentikan.

\section{Vigilantisme dan Kejahatan}

Apa yang dimaksud dengan Vigilantisme?secara etimologis, vigilantisme berasal dari kata "vigilante", yang berarti pengawas atau "pengawal". Sedangkan vigilantisme adalah gerakan main hakim sendiri (taking the law into one's own hands), termasuk penggunaan intimidasi dan cara-cara kekerasan, oleh warga sipil, baik dilakukan oleh individu atau kelompok sosial tertentu.Ia merupakan fenomena yang lumrah kita temui di semua masyarakat yang sedang ditimpa kemelut, ketika negara dianggap tidak mampu atau tidak efisien dalam menangani perkara.

${ }^{1}$ AKBP. Dr. Beridiansyah, S.H., M.H. adalah Dosen Matakuliah Kriminologi Pada Fakultas Hukum Unbari, Jambi, dan menjabat sebagai Kepala Detasemen Gegana Satbrimob Polda Jambi Email : Berdi.wira@gmail.com 
Berdasarkan motifnya, seperti yang ditulis dalam Vigilante Politics oleh H. Jon Rosenbaum dan Peter Sederberg, disebutkan bahwa ada 3 (tiga) tipologi vigilantisme, yakni : (1)vigilantisme kontrolkriminal, yang ditujukan untuk mengatasi terlalu maraknya kriminalitas; (2) vigilantisme kontrol kelompok sosial, yang dimaksudkan untuk mengawal entah kepentingan, otoritas, ataupun superioritas sistem nilai suatu kelompok sosial tertentu; (3) vigilantisme kontrol-rezim, yang dibentuk guna menggulingkan suatu rezim yang sedang berkuasa. ${ }^{2}$

Tindakan main hakim sendiri merupakan suatu respon masyarakat terhadap suatu peristiwa kejahatan yang malah menciptakan suasana tidak tertib.Masyarakat yang harusnya menaati hukum yang berlaku yang telah ditetapkan oleh penguasa bertindak sebaliknya, Tindakan main hakim sendiri lebih sering dilakukan secara massal untuk menghindari tanggung jawab pribadi serta menghindari pembalasan dari teman atau keluarga korban. Tindakan main hakim sendiri menunjuk kepada kekerasan yang dilakukan oleh massa (collective violence) terhadap orang-orang yang diduga sebagai penjahat.

Vigilantisme telah mengintervensi batas wewenang negara sehingga kegiatan itu sendiri tergolong kriminalitas.Reaksi dari masyarakat dalam menyikapi terhadap setiap persoalan yang terjadi secara berlebihan dengan mengabaikan norma-norma yang ada merupakan suatu bentuk kekacauan, Emile Durkheim mempergunakan istilah anomie yang diartikan suatu keadaan tanpa norma, dalam buku The Division of labour in society (1893),Durkheim mempergunakan istilah anomieuntuk mendeskripsikan keadaan "deregulation" didalam masyarakat yang diartikan sebagai tidak ditaatinya aturan-aturan yang terdapat pada masyarakat sehingga orang tidak tahu apa yang diharapkan dari orang lain dan keadaan memudahkan terjadinya penyimpangan perilaku (deviasi), Emile Durkheim mengatakanteori anomie terdiri dari 3 (tiga) perspektif, yaitu: (1) manusia adalah mahluk sosial (man is social animal); (2) keberadaan manusia sebagai mahluk sosial (human being is a social animal); (3) manusia cenderung hidup dalam masyarakat dan keberadaannya sangat tergantung pada masyarakat tersebut sebagai koloni (tending to live in colonies, and his/her survival dependent upon moral conections).

Teori anomie kemudian di adopsi oleh Robert K. Mertonyang meredefenisi Teorianomie sebagai ketidaksesuaian atau timbulnya diskrepansi/perbedaan antara cultural goals dan institutional means sebagai akibat cara masyarakat diatur (struktur masyarakat) karena adanya pembagian kelas. Dalam mencapai tujuan tersebut, ternyata tidak setiap orang menggunakan sarana-sarana yang tersedia, akan tetapi ada yang melakukan cara tidak sesuai dengan cara-cara yang telah ditetapkan (illegitimate means) hal ini terjadi dikarenakan struktur sosial berbentuk kelas-kelas sehingga menyebabkan adanya perbedaan kesempatan mencapai tujuan. Misalnya, mereka yang berasal dari kelas rendah (lower class) mempunyai kesempatan lebih kecil dalam mencapai tujuan bila dibandingkan dengan mereka yang berasal dari kelas tinggi (upper class)..$^{3}$

Rasa frustasi dan kegamangan dalam mensikapi realita kehidupan yang disebabkan oleh faktor ekonomi, sosial semakin menumbuh suburkan perilaku-perilaku yang bertentangan dengan norma-norma yang berlaku didalam masyarakat maupun norma hukum yang ada,Franz Magnis Suseno mengemukakan bahwa ada 4 (empat) konteks dimana tindakan kekerasan terhadap orang lain boleh dilakukan dan dibenarkan yaitu; (1) orang yang membela diri; (2) perang; (3) kekerasan yang perlu dilakukan alat negara dalam menegakkan hukum dan (4) hukuman yang diberikan oleh negara. ${ }^{4}$ Dengan demikian bahwa penggunaan kekerasan diluar konteks tersebut sudah barang tentu tidak dapat dibenarkan. Dengan perkataan lain, dalam latar belakang suasana apapun setiap orang tidak dibenarkan mengekspresikan kemarahan dan kebenciannya dengan cara menggunakan kekerasan, termasuk kekerasan yang dilakukan oleh sekelompok orang atau massa yang melakukan secara beramai-ramai terhadap orang yang diduga sebagai pelaku tindak pidana.

Selanjutnya, Franz Magnis Suseno, ${ }^{5}$ menyebutkan setidaknya ada 4 (empat) faktor membuat masyarakat bertindak dengan kekerasan, yaitu : (1) transformasi dalam masyarakat; (2) akumulasi kebencian dalam masyarakat; (3) masyarakat yang sakit dan; (4) sistem institusionalisasi kekerasan. Faktor transformasi budaya dalam masyarakat menunjuk pada ketidaksiapan masyarakat dalam menghadapi arus

\footnotetext{
${ }^{2}$ http://www.gusdur.net/id/mengagas-gus-dur/hentikan-vigilantisme-fpi, diunduh pada tanggal 29 Januari 2017.

${ }^{3}$ Made Darma Weda, Kriminologi, PT RajaGrafindo Persada, Jakarta, 1996, hal. 32.

${ }^{4}$ http://eprints.undip.ac.id/40709/2/BAB_II-DRAFT_DISERTASI-EDIT.pdf, diunduh pada tanggal 27 Januari 2017.

${ }^{5}$ Ibid.
} 
modernisasi dan globalisasi yang dianggap sebagai tekanan yang luar biasa dan membuat masyarakat dalam keadaan tegang terus menerus. Proses transformasi budaya dari masyarakat tradisional ke masyarakat pasca tradisional dengan sendirinya menciptakan disorientasi, dislokasi, disfungsionalisasi yang dirasakan sebagai ancaman ekonomis, psikologis dan politis. Faktor akumulasi kebencian dalam masyarakat menunjuk kepada adanya kecenderungan ekslusifisme di kalangan agama, dikalangan suku, golongan maupun kelompok.

Faktor masyarakat yang sakit menunjuk kepada keadaan dimana masyarakat begitu mudah terprovokasi.Hanya karena persoalan yang sederhana sudah dapat memicu kekerasan dan kekerasan ini bisa terjadi secara kolektif yang melibatkan komunitas-komunitas tertentu di dalam masyarakat.Sedangkan faktor yang terakhir menunjuk kepada pengaruh sistem institusionalisasi kekerasan penguasa masa lampau. Segala konflik sosial dipecahkan tidak secara rasional, tidak objektif, menghilangkan dialog, tidak adil melainkan secara kekuasaan: kooptasi, intimidasi, ancaman dan penindasan.

Negara Indonesia sebagai negara hukum tentunya semua perbuatan dan tindakan yang dilakukan oleh warga negaranya dilindungi oleh Undang-Undang dan aturan yang berlaku sebagaimana yang disebutkan dalam pasal 28D ayat 1 UUD 1945 bahwa "setiap orang berhak atas pengakuan, jaminan, perlindungan, dan kepastian hukum yang adil serta perlakuan yang sama dihadapan hukum", makna dari pernyataan tersebut penulis menafsirkan bahwa adanya jaminan yang disepakati bersama oleh pembuat dan perumus undang-undang tersebut yang merupakan perwakilan dari elemen masyarakat bahwa negara mengakui hakhak dan kewajiban yang dimiliki oleh warganya, dan pernyataan tersebut merupakan suatu bentuk toleransi yang ingin direalisasikan untuk menjamin keamanan, kenyamanan dan ketertiban bagi warga negaranya untuk menciptakan harmonisasi dalam melaksanakan pergaulan antar satu dengan yang lainnya.

Pemaksaan kehendak dan melanggar ketentuan yang telah disepakati dan disahkan oleh lembaga negara pada lembaran negara merupakan bentuk kejahatan.Apa yan dimaksud dengan Kejahatan ?Dilihat dari sosiologis bahwa kejahatan adalah salah satu jenis gejala sosial yang berkenaan dengan individu dan masyarakat. Dalam rumusan Paul Moedigno Moeliono Kejahatan adalah perbuatan manusia yang melanggar norma yang dirasakan merugikan, menjengkelkan, sehingga tidak boleh dibiarkan. Menurut B Simandjuntak bahwa Kejahatan adalah suatu tindakan anti sosial yang merugikan, tidak pantas, tidak dapat dibiarkan, yang dapat menimbulkan kegoncangan dalam masyarakat. ${ }^{6}$

Usaha untuk memahami kejahatan sebenarnya telah berabad-abad lalu dipikirkan oleh para ilmuwan terkenal.Plato (427-347 s.m.) dalam bukunya Republiek menyatakan antara lain bahwa emas, manusia adalah merupakan sumber dari kejahatan. Sementara itu Aristoteles (382-322) s.m.)menyatakan bahwa kemiskinan menimbulkan kejahatan dan pemberontakan. Kejahatan yang besar tidak diperbuat untuk memperoleh apa yang perlu untuk hidup, tetapi untuk kemewahan. Thomas Aquino (1226-1274) memberikan beberapa pendapatnya tentang pengaruh kemiskinan atas kejahatan. "orang kaya yang hidup untuk kesenangan dan memboros-boroskan kekayaannya, jika suatu kali jatuh miskin, mudah untuk menjadi pencuri". 7

Vigilantisme pada dasarnya merupakan pembalasan yang berawal dari konsep peradilan personal yang memandang kejahatan sebagai persoalan pribadi atau keluarga tanpa ada campur tangan penguasa. Individu yang merasa dirinya menjadi korban perbuatan orang lain, akan mencari balas terhadap pelakunya dan keluarganya. Konsep ini dapat ditemui pada perundang-undangan lama seperti pada Code Hammurabi (1900 S.M), pada masyarakat Yunani kuno seperti "curi sapi bayar sapi". Konsep kejahatan kemudian berkembang yaitu perbuatan-perbuatan yang ditujukan kepada raja seperti pengkhianatan, sedangkan terhadap perbuatan-perbuatan yang ditujukan terhadap individu masih menjadi urusan pribadi. Dalam perjalanan waktu kejahatan menjadi urusan raja (sekarang: negara) yaitu dengan mulai berkembangnya apa yang disebut sebagai "pariens patriae". Konsekuensi selanjutnya dengan diopernya tugas ini oleh negara maka tindakan vigilantisme dilarang. ${ }^{8}$

Tindakan main hakim sendiri (Vigilantisme)sering sekali terjadi diberbagai daerah di Indonesia. tindakan tersebut disertai dengan tindak kekerasan dengan menggunakan benda tumpul bahkan yang lebih tragis lagi disertai dengan menikam/menusuk atau membacok dengan menggunakan senjata tajam, bahkan

\footnotetext{
${ }^{6}$ Simandjuntak dan Pasaribu, Kriminologi, Tarsito, Bandung, 1984, hal. 45.

${ }^{7}$ Topo Santoso dan Eva Achjani, Kriminologi, RajaGrafindo, Bandung, 2001, hal. Ix.

${ }^{8}$ I.S. Susanto, Kriminologi, Fakultas Hukum Universitas Diponegoro, Semarang, 1991, hal. 3.
} 
pada kasus-kasus yang lain melakukan pembakaran terhadap orang yang diduga sebagai pelaku kejahatan. Pada dasarnya manusia melakukan kejahatan kerena faktor kondisi yang ada diluar dirinya, sehingga terjadinya kekerasan dipandang sebagai hal yang tidak wajar, yaitu suatu tindakan yang dipengaruhi oleh suatu kondisi struktural di luar diri manusia yang mengandung unsur kebetulan.

Dalam konteks faktor penyebab kekerasan, Theda Skocpol mengemukakan bahwa secara teoritik setidak-tidaknya terdapat dua pandangan yang berbeda mengenai faktor penyebab terjadinya kekerasan kolektif, yaitu inherensi (inherency) dan kontingensi (contingency), ${ }^{9}$ yaitu faktor yang ada di dalam diri manusia itu sendiri (internal) dan faktor yang ada diluar diri manusia (eksternal).

Kekerasan merupakan suatu yang inheren (inherence) pada diri manusia, sehingga manusia mempunyai potensi untuk melakukan kekerasan dalam mencapai tujuan-tujuannya. Menurut Erich Fromm menyatakan bahwa pada diri manusia terdapat 2(dua) jenis agresi yang sangat berbeda, yaitu agresi lunak dan agresi jahat. Agresi lunak dimaksudkan untuk mempertahankan diri serta bersifat adaptis biologis dan hanya muncul manakala ada ancaman, sedangkan agresi jahat yaitu kekejaman dan kedestruktifan, bukan merupakan pertahanan terhadap suatu ancaman, tidak terprogram secara filogenetik yang merupakan ciri khas manusia, dan secara biologis merugikan karena dapat mengacaukan tatanan sosial; perwujudan utamanya, yakni pembunuhan dan penyiksaan, bisa dinikmati tanpa membutuhkan tujuan lain; ia tidak hanya merugikan orang yang diserang, namun juga penyerang. Agresi jahat, meski bukan insting, merupakan kecenderungan manusia yang berakar dari kondisi kehidupannya. ${ }^{10}$

Potensi Inheren tidak bisa dihilangkan sama sekali, melainkan hanya dapat dicegah agar kekerasan tidak teraktualisasi atau terminimalisasi. Oleh karenanya pandangan inheren beranggapan bahwa kekerasan pada dasarnya merupakan salah satu cara untuk mengekspresikan kehendak dan memperjuangkan kepentingan politiknya. Sedangkan pandangan kontingensi (contingency) berpendapat bahwa kekerasan merupakan hasil dari kondisi struktural yang melingkupi manusia, seperti nilai, budaya, sosial, politik, ekonomi, dan lain-lain.

Dalam konteks pandangan kontingensi terdapat satu teori yang mengemukakan tentang sebab terjadinya kekerasan kolektif, yaitu teori deprivasirelatif (relative deprivation). Teori ini menjelaskan bahwa kekerasan terjadi karena adanya desakan dari kondisi struktural yang melingkupinya, dimana terjadi adanya kesenjangan antara apa yang diharapkan (value of expection) berbeda dengan kemampuan yang dimiliki untuk mencapai harapan itu (value of capabilities). Kesenjangan ini pada akhirnya menimbulkan frustasi pada diri seseorang atau masyarakat, yang dapat mendorongnya untuk melakukan tindakan kekerasan. ${ }^{11}$

Vigilantisme merupakan perbuatan yang tidak mencerminkan tujuan daripada hukum itu sendiri dalam konteks tujuan hukum menurut Gustav Radbruch adalah keadilan, kepastian dan kemanfaatan. Sehingga perilaku-perilaku yang mengarah kepada bentuk vigilantisme harus di tindak demi tegaknya supremasi hukum.

\section{Pendekatan Hukum Pidana dan Kriminologi terhadap Vigilantisme}

Vigilantisme selain sebagai kejahatan juga merupakan perilaku menyimpang, harus dijelaskan dengan melihat pada kondisi-kondisi struktural yang ada dalam masyarakat dan menempatkan perilaku menyimpang dalam konteks ketidakmerataan kekuasaan, kemakmuran dan otoritas serta kaitannya dengan perubahanperubahan ekonomi dan politik dalam masyarakat. ${ }^{12}$ Ukuran dari menyimpang atau tidaknya suatu perbuatan bukan ditentukan oleh nilai-nilai dan norma-norma yang dianggap sah oleh mereka yang duduk pada posisiposisi kekuasaan atau kewibawaan, melainkan oleh besar kecilnya kerugian atau keparahan sosial (social injuries).

Kriminologi sebagai ilmu pengetahuan yang mempelajari tentang kejahatan dan penjahat, kriminologi juga merupakan bagian ilmu yang mempelajari strategi untuk mencegah terjadinya kejahatan. Istilah Kriminologi pertama kali dipergunakan oleh Paul Topinard (1830-1911), menurut W.A. Bonger,

${ }^{9}$ Theda Skocpol, Negara dan Revolusi Sosial, terj. Kelompok Mitos, Jakarta: Erlangga, 1991, hal. 6-10.

${ }^{10}$ Lihat Enrich Fromm, Akar Kekerasan: Analisis Sosio-Psikologis atas watak Manusia, Yogyakarta: Pustaka Pelajar, 2000, hal. 257-260.

${ }^{11}$ Thedo Skckpol, Op.Cit.

${ }^{12}$ Topo Santoso dan Eva Achjani Zulfa, Ibid, hal. 14. 
Kriminologi bertujuan untuk menyelidiki gejala-gejala kejahatan seluas-luasnya. Menurut Bonger, pengertian seluas-luasnya itu berarti bahwa kriminologi juga mempelajari gejala-gejala lain dari Patologi sosial. Dalam memberikan batasan Kriminologi Bonger membagi kriminologi dalam 2 (dua) aspek yaitu : pertama, Kriminologi praktis yaitu kriminologi yang berdasarkan hasil penelitiannya disimpulkan manfaat praktisnya; kedua; kriminologi teoritis yaitu ilmu pengetahuan yang berdasarkan pengalamannya seperti ilmu pengetahuan yang sejenis.

Kejahatan yang besar tidak diperbuat untuk memperoleh apa yang perlu untuk hidup, tetapi untuk kemewahan. Bonger menempatkan satu lagi penulis masa lampau yaitu Thomas More. Penulis buku Utopia ini menceritakan bahwa hukuman berat yang dijatuhkan kepada penjahat pada waktu itu tidak berdampak banyak untuk menghapuskan kejahatan yang terjadi. Untuk itu katanya harus dicari sebabmusabab kejahatan dan menghapuskan kejahatan tersebut. ${ }^{13}$ Kejahatan sudah dikenal sejak adanya peradaban manusia. Makin tinggi peradaban, makin banyak aturan, dan makin banyak pula pelanggaran. Sering disebut bahwa kejahatan merupakan bayangan peradaban (crime is a shadow of civilization).Penentuan perbuatan mana yang dikehendaki dan tidak dikehendaki sepenuhnya bergantung kepada keseluruhan organisasi dan kultur masyarakat bersangkutan. ${ }^{14}$

Kejahatan (crime) merupakan tingkah laku yang melanggar hukum dan norma-norma sosial, sehingga masyarakat menentangnya, ${ }^{15}$ dalam konteks sosial, kejahatan merupakan fenomena sosial yang terjadi pada setiap tempat dan waktu. ${ }^{16}$ Hal ini menunjukkan bahwa kejahatan bukan saja merupakan masalah bagi suatu masyarakat tertentu yang berskala lokal maupun nasional, tapi juga menjadi masalah yang dihadapi oleh seluruh masyarakat dunia, pada masa lalu, kini dan masa yang akan mendatang, sehingga dapat dikatakan kejahatan sebagai a universal phenomenon. ${ }^{17}$

Kejahatan lebih dekat dari urat leher manusia, ketika kita menafikkannya dan mengatakan diri kita steril dari dosa kata itu, kita telah mengingkari keberadaan kita sebagai individu yang berinteraksi dengan mahluk sosial, karena dimana manusia ada disana ada kejahatan. Sebuah pernyataan yang tendesius dan seolah-olah menuduh, karena sebenarnya dalam peristiwa kejahatan, peran kita bisa sebagai pelaku, bisa sebagai korban, dan bisa pula kedua-duanya sekaligus.Bahkan, bisa mulai sebagai penonton langsung ketika kejahatan terjadi, atau sebagai penonton tak langsung. Ketika kita membantah kita tidak pernah berurusan dengan kejahatan dalam bentuk apapun, baik sebagai korban maupun sebagai pelaku, atau keduanya, bahkan sebagai penonton sekalipun, maka pada saat yang sama kita sebenarnya telah berperan sebagai bagian dari dinamika kejahatan itu sendiri; yaitu pengingkaran.

Kejahatan merupakan isu yang mempertemukan adanya ketertkaitan hubungan kriminologi dan hukum pidana dikarenakan objek studi kriminologi dan hukum pidana adalah sama-sama bertalian dengan masalah kejahatan. Objek studi kriminologi adalah dalam rangka mencari sebab-sebab terjadinya kejahatan, artinya untuk menjawab pertanyaan, apa yang menyebabkan seseorang itu melakukan kejahatan atau kenapa seorang menjadi penjahat. Sedangkan objek studi hukum pidana adalah terkait dengan masalah aturanaturan tentang kejahatan, serta bagaimana pidana itu dijatuhkan manakala terjadi pelanggaran terhadap aturan tersebut.

Kejahatan sebagai gejala sosial tidak semata-mata merupakan tindakan yang dilarang oleh hukum, bukan merupakan tindakan yang merupakan kelainan biologis maupun kelainan psikologis, menurut Durkheim menyebutkan kejahatan sebagai gejala yang normal karena tidak mungkin ada masyarakat tanpa kejahatan. Rumusan tersebut menyanggah bahwa kejahatan bukanlah kelainan sosial yang harus dimusnahkan atau diberantas. Kenormalan kejahatan semata-mata bahwa keberadaannya atau tingkat kemunculannya tidak melampaui tingkat yang memungkinkan masyarakat mampu mengendalikannya.

Meskipun kejahatan secara kriminologis merupakan konsep sosial, pada akhirnya apabila tindakan tersebut dianggap sangat merugikan oleh masyarakat, maka ia akan menjadi pengertian kejahatan yang

\footnotetext{
${ }^{13}$ Topo, dkk, Kriminologi, Raja Grafindo Persada, Jakarta, 2001.

${ }^{14}$ http://eprints.undip.ac.id/20293/1/2416-ki-fh-98.pdf, diunduh pada tanggal 22 Januari 2017.

${ }^{15}$ Kartini kartono, Patologi Sosial, Jilid I Edisi Baru (Jakarta: Rajawali Press, 1992), hal. 134.

${ }^{16}$ Andi Matalata, "Santunan Bagi Korban", dalam J.E. Sehetapy, Victimologi sebuah Bunga Rampai (Jakarta: Pustaka Sinar

${ }^{17}$ Barda Nawawi Arief, Kebijakan Legislatif dalam penanggulangan kejahatan dengan hukum pidana, (Semarang: Ananta,
} Harapan, 1987), hal.35. 1994), hal. 2. 
dicantumkan dalam hukum pidana sebagai tindakan yang dilarang dilakukan, dan kepada pelakunya diancam dengan sanksi hukuman. Pencantuman suatu tindakan kedalam hukum pidana melalui proses sosial dan proses politik. Proses-proses tersebut bermuara pada kewenangan legislatif (badan pembuat undangundang) untuk mencantumkan atau tidak mencantumkan suatu tindakan sebagai kejahatan dalam hukum pidananya.

Proses perumusan suatu tingkah laku menjadi kategori kejahatan dalam hukum tersebut di atas tampaknya sederhana. Dalam kenyataannya proses tersebut berjalan penuh dinamika, terjadi tarik ulur antar pihak yang berkepentingan untuk merumuskan atau tidak merumuskan suatu tingkah laku sebagai tindakan kejahatan. Dinamika tersebut merupakan proses politik yang di Indonesia menurut Undang-Undang Dasar 1945, perumusan suatu pelanggaran nilai dan norma ke dalam rumusan hukum merupakan tugas legislatif (DPR dan DPD) bekerjasama dengan lembaga dirumuskan oleh suatu negara merupakan pencerminan aspirasi warga negaranya, dalam praktik perumusan tersebut sangat dipengaruhi oleh kepentingan kelompok-kelompok yang terlibat dalam proses pembuatan hukum, yaitu partai-partai politik dan kelompokkelompok kepentingan. ${ }^{18}$

Untuk menentukan perbuatan yang dalam kriminologi merupakan perilaku menyimpang agar dapat disebut sebagai kejahatan menurut hukum pidana yakni melalui kriminalisasi yaitu menentukan perbuatan tersebut sebagai tindak pidana menjadi tindak pidana; dekriminalisasi, yaitu menentukan suatu perbuatan yang sebelumnya sebagai tindak pidana menjadi bukan tindak pidana; dan depenalisasi yaitu menentukan suatu perbuatan yang sebelumnya dapat dipidana menjadi perbuatan yang tidak dipidana.

Penegakan hukum terhadap semua jenis kejahatan yang melanggar norma dan aturan yang berlaku terus dilakukan baik menggunakan sarana penal maupun non penal, namun tindak kejahatan terus terjadi sejalan dengan kejahatan tersebut termasuk juga terhadap tindakan vigilantisme yang dilakukan oleh masyarakat menimbulkan kecemasan dan keraguan pada masyarakat akan kemampuan aparat penegak hukum untuk memberikan perlindungan bagi warga negaranya dari intimidasi dan tindakan vigilantisme yang semakin sering terjadi. Tidak hanya itu saja, menurut Firya Oktaviarni, undang-undang sebelumnya dianggap tidak mampu untuk menjawab tantangan dan harapan ke depan. ${ }^{19}$

Dengan demikian, tidak hanya kemampuan aparat penegak hukum saja yang menjadi perhatian, aturan undang-undang juga harus mendapat perhatian guna melindungi orang dari suatu kejahatan.

Menurut pendapat penulis bahwa Tindakan Vigilantisme merupakan "luapan emosi yang tidak tersalurkan" ada beberapa alasan penulis untuk mengatakan demikian, diantaranya : (1) lambatnya penanganan dan proses hukum terhadap para pelaku kejahatan yang seolah-olah para pelaku kejahatan tidak dapat tersentuh oleh aturan hukum positif yang berlaku; (2) turunnya tingkat kepercayaan masyarakat terhadap kinerja aparat penegak hukum; (3) tidak sesuainya keinginan dan harapan masyarakat terhadap realita kehidupan yang ada. Keadaan tersebut menurut Penulis menjadi salah satu dari kesekian faktor yang memunculkan dan makin maraknya tindakan vigilantisme di tengah-tengah masyarakat.

Konsistensi dalam penegakan hukum terhadap segala bentuk tindakan yang melanggar norma harus diterapkan secara tegas sehingga tidak terkesan tebang pilih dan sikap betul-betul netral tanpa adanya intervensi dari siapapun sangat diperlukan untuk melakukan pencegahan terhadap berkembangnya perilakuperilaku yang bertentangan dengan norma-norma yang berlaku. Selain dari pada penegakan hukum upayaupaya sosialisasi dan pendekatan secara personal juga sangat diperlukan untuk mengetahui latar belakang permasalahan yang terjadi, upaya sinergitas antar semua komponen lembaga yang ada sangat diperlukan untuk mencegah terjadinya tindakan-tindakan main hakim sendiri.

Hukum berfungsi sebagai kontrol sosial menurut Roscoue Pound, fungsi utamahukum adalah untuk melindungi kepentingan yang ada dalam masyarakat ada 3 (tiga) kepentingan yang harus dilindungi yaitu : (1) Public Interest; (2) Individual Interest; (3) interest of personality. Hukum sebagai Panglima dalam upaya mencapai keadilan dan kepastian hukum serta perlakuan sama dimuka hukum, sangat diharapkan oleh semua warga negara dengan adanya ketegasan dalam penegakan hukum akan berpengaruh terhadap keamanan dan ketertiban ditengah-tengah masyarakat.

\footnotetext{
${ }^{18}$ Muhammad Mustofa, Kriminologi kajian sosiologi terhadap kriminalitas perilaku menyimpang dan pelanggaran hukum, Fisip UI Press, Jakarta, 2007, hal.22

${ }^{19}$ Firya Oktaviarni, Perlindungan Hukum Terhadap Wisatawan Menurut Undang-Undang Nomor 10 Tahun 2009 Tentang Kepariwisataan, Wajah Hukum Volume 2 Nomor 2, Oktober 2018, hal.140
} 
Penegakan hukum adalah proses dilakukannya upaya untuk tegaknya atau berfungsinya norma-norma hukum secara nyata sebagai pedoman perilaku manusia dalam melakukan kontak sosial. Menurut Soerjono Soekanto ada beberapa faktor yang sangat menentukan dalam penegakan hukum yang berguna bagi masalah penegakan hukum dalam masyarakat yaitu: 1) Faktor Hukumnya Sendiri; 2) Faktor Penegak Hukum; 3) Faktor Sarana atau Fasilitas; 4) Faktor Masyarakat; 5) Faktor Kebudayaan. Kelima faktor tersebut sangat berkaitan dengan erat karena merupakan esensi dari penegakan dan merupakan tolok ukur dari pada efektivitas penegak hukum.

Korelasi pendapat Soerjono Soekanto terhadap faktor penegakan hukum dan berkembangnya tindakan vigilantisme menurut penulis bahwa perlunya konsistensi dan moral selain dari pada ke 5 (lima) faktor tersebut, karena penegakan hukum terus dilakukan oleh aparat penegak hukum terhadap semua jenis kejahatan yang terjadi namun kejahatan yang terjadi terus mengalami peningkatan, ada sesuatu permasalahan dalam proses penegakan hukumnya sehingga sanksi hukum yang diberikan tidak membuat efek jera, padahal tujuan dari pembinaan hukum adalah membuat jera dan agar para pelaku kejahatan tidak mau mengulangi lagi perbuatannya.

Penegakan hukum selalu melibatkan manusia didalamnya dan melibatkan juga tingkah laku manusia. Hukum tidak dapat tegak dengan sendirinya, artinya hukum tidak mampu mewujudkan sendiri janji-janji serta kehendak-kehendak yang tercantum dalam (peraturan-peraturan) hukum. Penegakan hukum tidak berarti hanya melaksanakan peraturan perundang-undangan semata, tetapi bagaimana peraturan perundangundangan itu diterapkan masih tergantung pada beberapa faktor yang dapat mempengaruhinya. Selain ditentukan atau tergantung keadaan masyarakat untuk mentaati hukum itu, juga ditentukan dari peran aparat penegak hukum (law enforcement officers) baik dalam hal menegakkan hukum (law enforcement) maupun dalam hal memelihara ketertiban/kedamaian (peace maintenance).

Dalam penegakan hukum pidana peranan aparat penegak hukum begitu dominan, dominasi peran tersebut merupakan representasi negara dalam melakukan penegakan hukum atas dasar kewenangan yang dimilikinya sebagai wakil sah dari masyarakat untuk melakukan penuntutan terhadap pelanggar hukum pidana. Bagaimana kemudian hukum pidana dapat dilaksanakan oleh aparat penegak hukum dengan baik, maka untuk itu dibutuhkan komitmen dan konsistensi aparat penegak hukum dalam melaksanakan penegakan hukum. Sehubungan dengan hukum yang sulit untuk ditegakkan Moh. Mahfud MD menyatakan : " seluruh teori dan konsep sudah habis dikeluarkan, tak ada yang tersisa untuk ditawarkan. Bahkan teori penyebab ketidakmanjuran teori yang dipakai pun sudah habis". ${ }^{20}$

Semakin maraknya persoalan vigilantisme di Indonesia harus disikapi dengan serius karena permasalahan tersebut muncul karena ketidakpercayaan kemampuan kinerja aparat penegak hukum, kalangan sipil mengangkat diri sendiri sebagai pihak yang berwenang untuk menerapkan pemberlakuan hukum dan mempertahankan tatanan sosio-politik, vigilantisme semakin berkembang pada saat sistem hukum tidak berjalan dengan baik, kurang tegasnya terhadap penanganan kasus-kasus vigilantisme juga menjadi faktor penyebab makin berkembangnya kasus-kasus serupa. Tindakan main hakim sendiri dikemas dalam bentuk apapun jelas tidak boleh terjadi karena tindakan main hakim sendiri merupakan tindakan pidana sebagaimana yang diatur dalam pasal 170 KUHP sebagai berikut :

(1) Barang siapa yang di muka umum bersama-sama melakukan kekerasan terhadap orang atau barang, dihukum penjara selama-lamanya lima tahun enam bulan.

(2) Tersalah dihukum:

- Dengan penjara selama-lamanya tujuh tahun, jika ia dengan sengaja merusakkan barang atau kekerasan yang dilakukannya itu menyebabkan sesuatu luka.

- Dengan penjara selama-lamanya sembilan tahun, jika kekerasan itu menyebabkan luka berat pada tubuh.

- Dengan penjara selama-lamanya dua belas tahun, jika kekerasan itu menyebabkan matinya orang.

Dalam konteks kekerasan, Max Weber sebagaimana dikutip I. Wibowo, menyatakan: negara memegang "the monopoly of legitimate use of physical force", tidak ada kelompok lain dimasyarakat yang boleh memakai kekerasan dalam bentuk apapun kecuali aparat negara. Tujuannya dimaksudkan adalah

${ }^{20}$ Moh. Mahfud MD, Hukum Tak Kunjung Tegak, Cetakan ke 1, Citra Aditya Bakti, Bandung, hal. 79. 
untuk menjaga kedaulatan negara sekaligus menjaga ketertiban dalam masyarakat. Tertib masyarakat akan hancur jika tidak ada monopoli pemakaian kekerasan.

\section{SIMPULAN}

Vigilantisme merupakan permasalahan sosial pada masyarakat yang muncul karena kurangnya keperdulian, ketidak Profesionalan dari aparat yang berwenang dalam merespon permasalahan yang terjadi ditengah-tengah masyarakat sehingga timbul rasa ketidak percayaan terhadap kemampuan dan netralitas dari aparat penegak hukum, rendahnya kesadaran hukummemudahkan berkembangnya pemikiran-pemikiran sempit dalam mensikapi setiap permasalahan yang terjadi.

Peranan aparat penegak hukum serta kesadaran hukum masyarakat untuk mencegah terjadi tindakan massa yang bertentangan dengan hukum harus dihentikan karena tindakan tersebut bukan merupakan solusi dari permasalahan namun akan dapat menimbulkan anomie dalam kemajemukan masyarakat Indonesia, kriminologi dan hukum pidana merupakan satu komponen yang tidak dapat dipisahkan untuk mencari penyebab dan juga untuk melakukan penindakan tindakan main hakim sendiri tersebut. Sinergitas dan soliditas serta pendekatan-pendekatan dengan memberikan pemahaman hukum kepada masyarakat akan sangat membantu untuk mencegah tindakan main hakim sendiri terus berkembang karena negara kita merupakan negara hukum dan dalam sistem hukum kita seseorang tidak dapat dengan begitu saja divonis bersalah oleh siapapun tanpa melalui proses hukum, karena bersalah atau tidaknya seseorang terduga telah melakukan tindak kejahatan harus dibuktikan dipengadilan dan hakim yang memutuskan bersalah atau tidaknya pelaku kejahatan.

\section{DAFTAR PUSTAKA}

\section{Books}

Andi Matalata, "Santunan Bagi Korban”, dalam J.E. Sehetapy, 1987,Victimologi sebuah Bunga Rampai (Jakarta: Pustaka Sinar Harapan).

Barda Nawawi Arief, 1994,Kebijakan Legislatif dalam penanggulangan kejahatan dengan hukum pidana, (Semarang: Ananta).

Enrich Fromm, 2000,Akar Kekerasan: Analisis Sosio-Psikologis atas watak Manusia, Yogyakarta : Pustaka Pelajar.

I.S. Susanto, 1991,Kriminologi, Fakultas Hukum Universitas Diponegoro, Semarang.

Kartini kartono, 1992, Patologi Sosial, Jilid I Edisi Baru (Jakarta: Rajawali Press).

Made Darma Weda, 1996, Kriminologi, PT RajaGrafindo Persada, Jakarta.

Moh. Mahfud MD, Hukum Tak Kunjung Tegak, Cetakan ke 1, Citra Aditya Bakti, Bandung.

Muhammad Mustofa, 2007,Kriminologi kajian sosiologi terhadap kriminalitas perilaku menyimpang dan pelanggaran hukum, Fisip UI Press, Jakarta.

Simandjuntak dan Pasaribu, 1984,Kriminologi, Tarsito, Bandung.

Topo Santoso dan Eva Achjani, 2001,Kriminologi, RajaGrafindo, Bandung.

Theda Skocpol, 1991,Negara dan Revolusi Sosial, terj. Kelompok Mitos, Erlangga, Jakarta.

\section{Website}

http://www.gusdur.net/id/mengagas-gus-dur/hentikan-vigilantisme-fpi

http://eprints.undip.ac.id/40709/2/BAB_II-DRAFT_DISERTASI-EDIT.pdf.

http://eprints.undip.ac.id/20293/1/2416-ki-fh-98.pdf.

\section{Jurnal}

Firya Oktaviarni, Perlindungan Hukum Terhadap Wisatawan Menurut Undang-Undang Nomor 10 Tahun 2009 Tentang Kepariwisataan, Wajah Hukum Volume 2 Nomor 2, Oktober 2018 